\title{
ФРАЗЕОЛОГИЗМЫ С КОМПОНЕНТОМ УХО
}

\section{Рыбакина Анастасия Сергеевна}

студент

Брянский Государственный Университет имени академика И.Г. Петровского

Аннотация: в статье рассмотрены фразеологизмы с компонентом ухо на примере немецкого и русского языков. Как показывает материал, искомые фразеологизмы является транслятором того, какой объём культурной информации носители языка подразумевают, используя компонент ухо в устойчивых оборотах языка. Ухо - разведка; доверчивость и даже глупость человека.

Ключевые слова: фразеологизм, компонент ухо, значение, ассоциация, оценка.

\section{PHRASEOLOGY WITH THE EAR COMPONENT}

\section{Rybakina Anastasia Sergeevna}

\begin{abstract}
: the article considers phraseological units with the ear component on the example of German and Russian. As the material shows, the required phraseological units are a translator of how much cultural information native speakers mean by using the ear component in stable language turns. Ear - intelligence; credulity and even stupidity of a person.

Key words: phraseology, ear component, meaning, association, evaluation.

«Ухо - орган слуха и равновесия у человека и позвоночных животных» [1].

В мире существует множество фразеологизмов (ФЕ). Затрагивая ФЕ с компонентом ухо, можно заметить, что множество фразеологизмов хоть и звучат по-разному, но ориентированы на схожую мысль. Ухо - это не просто орган слуха, а средство получение той или иной информации. Оно помогает подслушивать и узнавать секретные данные и информацию о человеке, которую тот хочет скрыть. Рассмотрим фразеологизмы с компонентом ухо в русском и немецком языках.
\end{abstract}


Один из самых популярных и часто употребляемых ФЕ в русском языке с компонентом ухо звучит следующим образом И у стен есть уши [2]. Конечно, это не значит, что у стен действительно есть какой-либо орган слуха. На самом деле речь идет о людях, точнее о тех, кто подслушивает кого-либо, при этом его местоположение недалеко от говорящего. Раньше, бывали случаи, когда люди могли сдать своих соседей и близких друзей, если они услышали, например, критику в сторону правительства. После чего наказывались люди, которые выражали свое недовольство, а сдавшим соседям поощрялся их поступок. Стены были не такие уж толстые, поэтому было хорошо слышно голоса и звуки. Конечно, и в наше время можно встретить людей, которые могут говорить шепотом, так как боятся, что кто-то третий может услышать секретный разговор. Интересный факт, что данный ФЕ впервые встречается в испанской литературе - в пьесе (действ. 2, явл. 8) «Валенсианская вдова» (1620) испанского драматурга Лопе де Вега (1562-1635), позже - в романе «Дон Кихот» (1605-1615) Мигеля Сервантеса де Сааведра (1547-1616). [3] В пьесе Лопе де Веги «Валенсианская вдова», написанной в первой половине XVII века, есть такие строки: «Так безрассудно говорить на ветер И не подумать, что моим речам Внимают эти мыслящие тени! Итак, стена, и у тебя есть уши» [4]. Данный ФЕ нашел отражение и в произведение Мигеля Сервантеса де Сааведра «Дон Кихот»: «Нет уж, я лучше помолчу, а то ведь и у стен бывают уши» [5]. Из чего мы можем предположить, что именно испанский драматург Лопе де Вега является автором или одним из первых людей, кто употребил данный ФЕ. Однако стоит заметить, что конечный вариант «Валенсианская вдова» считается 1620 год, а «Дон Кихот» первый том был создан в 1605 году. Поэтому, можно сделать поспешный вывод, что именно Мигель Сервантес де Сааведра употребил данное выражение раньше Лопе де Вега, но это не так. Ведь ранний вариант пьесы был написан около 1604 года, а в 1618-1619 гг. Лопе де Вега подверг свое произведение некоторой переработке. А само произведение можно считать полностью готовым именно в 1620 году. Из этого следует, что именно испанский драматург Лопе де Вега употребил данный фразеологизм первым. ФЕ И у стен есть уши [2] стал устойчивой метафорой и символом любого подслушивания. Конечно, ФЕ стал популярен не только в Испании, где он и зародился, но и в ряде других странах, например, таких как Россия и Германия. Стоит заметить, в русский и немецкий языки внедрился особенно крепко. Ведь данные языки - международные языки. На них говорят множество людей в мире. По статистике 260 миллионов человек говорят на 
русском. Это 8-й результат в мире. Он попадает в топ-5 самых сложных языков мира. А на немецком языке могут говорить 185 миллионов человек. Русский ФЕ уже упоминался ранее и звучит следующим образом Иу стен есть уши [2]. В Германии ФЕ выглядит следующим образом Auch die Wände haben Ohren. (букв.: также стены имеют уши) [6, с. 437]. Можно увидеть почти полностью тождественные фразеологизмы. Также и И - это единственная разница в данных версиях ФЕ. Они несут схожую смысловую нагрузку и обозначают одно значение «а также», то есть, помимо людей, и неодушевленной стены, могут иметь уши. Конечно, мы понимаем что имеется в виду, что за стеной сидит человек и Греет уши [2], то есть подслушивает. Русский ФЕ Греть уши [2] употребляется в неодобрительном смысле. Однако в отличие от предыдущих примеров, ФЕ относят к уголовному жаргону.

Существуют ФЕ с компонентом ухо, которые несут мысль о разведке. Русский ФЕ Глаза и уши [2]. Так иносказательно называют людей, занимающихся разведкой и наблюдением. Пример данного фразеологизма можно увидеть в повести Эммануила Генриховича Казакевича «Звезда» «Разведчики стояли молча, переминаясь с ноги на ногу. Вид у них был довольно жалкий. - Вот они, твои глаза и уши, - пренебрежительно сказал комдив начальнику штаба и сел в машину» [7]. Глаза и уши - люди, а точнее разведчики, которые следят и добывают информацию о конкретных людях, возможно и врагах. Данной повести, как никогда, подходит данный ФЕ. Ведь в центре сюжета - суровые будни советской разведки во время Великой Отечественной войны. В немецком языке также существуют фразеологизмы, которые можно отнести к разведке Der Tag hat Augen, die Nacht hat Ohren (букв.: день имеет глаза, ночь имеет уши) [6, с. 437]. То есть, днем могут наблюдать издалека глазами, а ночью, когда темно, на расстояние слушать вблизи. Значение секретности несет немецкий ФЕ Der Busch hat Ohren, das Feld hat Augen. (букв.: куст имеет уши, а поле глаза) [6, с. 437]. На первый взгляд не совсем понятно, о чем идет речь. Однако в немецком языке рядом с фразеологизмом можно увидеть пояснение Geheimnisse muss man überall hüten (букв.: тайны должны везде оберегаться) [6, с. 437]. То есть человек должен быть осторожен, где он бы не был. Каждый кустик может слышать, и даже на поле есть глаза. То есть за ним могут следить, поэтому ему следует оберегать свои тайны, где бы он ни был.

Конечно, существуют и другие ФЕ, которые употребляются в жизни с компонентом ухо. В русском языке Развесить уши [2] - слушать с чрезмерным 
увлечением, всему доверять. Существует версия происхождения данного фразеологизма. На самом деле данная ФЕ появилась, как и многие великие открытия, с помощью наблюдения за природой, а точнее за собакой. Это домашнее животное имеет не только, как мы знаем острый нюх, но и необыкновенные уши. Животные довольно восприимчивы к звукам, и конечно собака не исключение. Если она слышит незнакомый голос или какой-то другой чужой для нее звук, она приподымает уши. Так собака дает понять, что есть опасность для нее и хозяина. Как только она удостоверится в том, что опасности нет, ее уши опустятся. Хозяин же должен поблагодарить «верного друга» за его внимательность. [8] Однако в реальной жизни данный ФЕ несет мысль, что человек безоговорочно верит в то, что ему говорят. Он ни секунды не сомневаться в сказанном ему собеседником. Возможно, это можно понять следующим образом, люди хотят верить услышанному, при этом сравнивая свой слух и собаки. Однако в современном мире многие злоупотребляют доверчивостью людей, например маркетологи. Для них существуют специальные выражения, которыми они могут завлечь потенциальных покупателей. Они помогут воздействовать на людей психологически и принудить купить вещь, которая покупателю и вовсе не нужна, но после разговора с продавцом станет жизненно необходима. Такие слова и выражения как «Новинка», «Ограниченное количество», «Бесплатный», «Эксклюзивное предложение» и так далее, действительно заставляют покупателей Развесить уши и купить товар. «Одно слово может изменить твое решение. Одно чувство может изменить твою жизнь. Один человек может изменить тебя». Конфуций. [9] Так и ФЕ Развесить уши может охарактеризовать то или иное решение человека, которое изменило его жизнь. В немецком языке Das Ohr hat keine Türen (букв.: у уха нет дверей) [6, с. 437]. То есть Man kann es nicht verschließen (букв.: не можешь его закрыть) [6, с. 437]. Немецкий ФЕ, как и русский имеет схожую идею. Даже если хочется, то не получается закрыть ухо и приходиться слушать информацию, независимо от того нужна ли она или нет. Человек будет слушать, и, в конце концов, он ей довериться.

Один из ярких ФЕ в русском языке, где идет речь о доверии и обмане Bешать лапиу на уии [2]. Конечно, лапша - это не еда, а метафора. Лапша информация. ФЕ несет в себе ироничный оттенок и обозначает нести какуюлибо чушь или небылицу. Одна из версий происхождений принадлежит к миру криминалистики. Данный ФЕ относиться к значению «Ложное обвинение». Глагол «лапшить» преступники использовали для обозначения «фабрикации 
улик или уголовного дела», в котором обвиняли человека. Данный глагол, возможно, образовался от продукта питания лапши, а точнее процесса ее изготовления. Раньше лапшу изготавливали следующим образом: скатывали тонкий пласт из теста в рулет, а затем тонко шинковали ножом, превращая в мелкое крошево. [10] Данный процесс ассоциируется с действиями человека, когда он врет. Он совершает множество быстрых движений, произносит много слов, суетиться. Он будто крошит лапшу, тем самым и навешивая ее на уши. Он говорит небылицы, а его собеседник слушает это.

Бывают случаи, когда человека и обманывать особо не нужно, потому что он сам не совсем понимает, о чем идет речь. В немецких ФЕ Bei tauben Ohren ist jede Predigt verloren (букв.: в глухих ушах любая проповедь потеряна) [6, с. 437] и Tauben Ohren predigt man vergebens (букв.: глупым ушам напрасно читать проповедь) [6, с. 437] мы можем увидеть, что, сколько ни говори человеку какую-либо информацию, он не поймет ее суть. В русском языке ФЕ Ни уха, ни рыла не смыслить [2] - это грубая форма высказывания о человеке, который не понимает предмета обсуждения.

Изучив данные фразеологизмы, мы можем прийти к выводу, что в немецком и русском народе лексема ухо часто употребляется в значение разведки, доверчивости и даже глупости. Большая часть ФЕ относится к попытке выведать ту или иную информацию. Важно отметить, что компонент ухо употребляется во многих немецких и русских фразеологизмах, и значения ФЕ, которые передают те или иные народы, схожи друг с другом.

\section{Список литературы}

1. Словарь [Электронный ресурс]. - Режим доступа: https://dic.academic.ru/dic.nsf/enc_colier/3748/УXО- (дата обращения: 18.01.22).

2. Русские фразеологизмы [Электронный ресурс]. - Режим доступа: https://madamelavie.ru/frazeologizmy/frazeologizmy_uho_ushi/ - (дата обращения: 18.01.22).

3. Испанская литература [Электронный ресурс]. - Режим доступа: https://www.diagram.com.ua/idioms/idioms1001.shtml - (дата обращения: 18.01.22).

4. «Валенсианская вдова» [Электронный ресурс]. - Режим доступа: http://lib.ru/DEVEGA/vdova.txt - (дата обращения: 18.01.22). 
5. «Дон Кихот» [Электронный ресурс]. - Режим доступа: https://www.litmir.me/br/?b=86213\&p=136 - (дата обращения: 18.01.22).

6. Sprichwörterlexikon: Sprichwörter u. sprichwörtl. Ausdrücke aus dt. Sammlungen vom 16. Jh. bis zur Gegenwart / Horst u. Annelies Beyer. - 4., unveränd. Aufl. - Leipzig : Bibliographisches Institut, 1988. - 712 S. : 204 I11.

7. «Звезда» [Электронный ресурс]. - Режим доступа: https://www.litmir.me/br/?b=172038\&p=1 - (дата обращения: 18.01.22).

8. Про собаку и уши [Электронный ресурс]. - Режим доступа: https://heaclub.ru/razvesit-ushi-proishozhdenie-pryamoe-i-perenosnoe-znacheniefrazeologizma-obyasnenie-odnim-slovom-primery-predlozhenij\#i $\quad-\quad$ (дата обращения: 18.01.22).

9. Конфуций [Электронный ресурс]. - Режим доступа: https://artemiroshnikov.ru/blog/130-ceplyayushchih-fraz-i-slov-magnitov-dlya-pokupateley (дата обращения: 18.01.22).

10. Лапша [Электронный pecypc]. - Режим доступа: https://nadostupnom.ru/veshat-lapshu-na-ushi/ - (дата обращения: 18.01.22). 